\title{
Perception of Environmental Risk Factors Scale for the primary school students
}

\author{
Nilüfer Özabaci ${ }^{1}$ \\ Eda Yeşilkaya ${ }^{2}$
}

\begin{abstract}
The purpose of this study was to develop a scale to determine the effect of perception of environmental risk factors on primary school students. The participants of this study were 409 students of both low and high socio-economic level from 2 primary schools in Gaziantep. Confirmatory factor analysis and path analysis were used for scale development study. As a result of the analysis, it has been determined that the scale has a structure composed of six subscales and 55 items. Subscales of the scale are; perceptions of in school experience, perceptions of oneself, perceptions of family attitudes, perceptions of family interactions, perceptions of problems within the family, perceptions of the nearest living area. Cronbach Alpha for the scale was found to be .85 .
\end{abstract}

Keywords: Environmental Factors, Risk; Primary School Children; Scale Development.

\section{Introduction}

In recent studies, it has been revealed that many factors affect a child's development including individual and family variables, in addition focus on school and environment related variables are necessary to better understand the child development. Environmental factors such as relations with the family members, health problems, school and house, socio-economic conditions affect the development of individuals positively or negatively. It can be said that environment-related factors have an important effect on children's physical, cognitive and psychosocial development (Bronfenbrenner, 1979).

Risk is defined as the condition where by an encounter with environmental or biological factors increases the probability of negative developmental outcomes (Brooks-Gunn, Klebanov, Liaw \& Spiker, 1993). Assessing the problems which are experienced during childhood, it is not possible to talk about only one risk factor and studies shows that with occurrence of problem behaviors there are some common causes. The common causes can be considered as gender, age, socio-economic level of the family (Bearinger, Blum, Resnick Saewyc \& Skay, 1998). Risk factors can also be defined as terms and variables such as concessions of health, well being and social performance which increases the probability of occurence of undesirable outcomes (Jessor, Bos, Costa, Turbin \& Vanderryn, 1995; Brooks-Gunn, Klebanov, Liaw, Spiker, 1993).

It can be said that when children are exposed to multiple risks, these risks may affect them negatively and determining the total risk faced by children has critical importance for predicting children's behavioral non-compliance or failure (Garmezy, 1985; Sameroff, Seifer, Baldwin \& Baldwin, 1993). Sameroff and et al. (1993) listed ten social risk factors in presented the pattern at

${ }^{1}$ Prof. Dr., Eskişehir Osmangazi University, Guidance and Counceling, niluferozabaci@hotmail.com

${ }^{2}$ Doctoral Student on the Program of Teacher of MEB in USA. yesilkayaeda@,hotmail.com 
Özabacı, N., \& Yeșilkaya, E. (2016). Perception of Environmental Risk Factors Scale for the primary school students. Journal of Human Sciences, 13(2), 3150-3159. doi:10.14687/jhs.v13i2.3743

their study such as mother's behavior, mother's developmental beliefs, mother's anxiety, mother's mental health, mother's educational attainment, family social support, family size, majör stressful life events, occupation of head of household, and disadvantaged minority status. Burchinal, Hooper, Roberts, Neebe and Zeisel (1998) suggested ten substances in context of family risk factors which based on Sameroff's risk model: poverty status, maternal education less than high school, household size, unmarried mother, stressful life events, depressed maternal affect, motherinfant interactions, maternal IQ, the quality of the home environment, and quality of the day care environment.

It should be noted that many factors which are in the vicinity of the individual affect the development of individual. Bulut (2010) examined illegal behavior of adolescents in terms of family risk factors, family functioning and quality of life. He also noted illegal behavior's prevalence may be associated with parent's educational level, income level, stable home situations authoritarian attitudes and presence of individuals which have mental disorders.

When the studies relating to environmental risk factors are examined, there is a scale created by Jessor, Costa and Turbin (2004). This scale is refered to as "Adolescence Health Development Questionare". It contains sub-dimensions related to the environmental factors such as school, family and peer relationships. This scale was adopted for use in Turkey by Siyez (2006) with the name of " Adolescence Development and Health Education Inventory (Ergen Gelişimi ve Sağllğ1 Envanteri)". Ünal (2006) examined student's attitudes about the future in his scale which include the seventh and eight grades. This scale is likert type questionare that items prepared with triple. According to the study, it was concluded that some factors such as to to be happy in school and school activities, to think they are a good person, to think that the people like them around, positive attitudes of parents, education level of parents, to be affective and positive attitudes for he future of students. Erkan (2002) used a family risk factors list which measured whether social anxiety level varied according to gender and parents attitudes.

Öztürk, Sevindik and Yaman (2006) whose examined university students' social support and loneliness status, noted that students parental attitudes had significant relationship with social support. A number of existing studies contributed to the development of Perceptions of the Environmental Risk Factors Scale. Those studies used Bronfenbrenner ecological systems theory (1979), Sameroff et al. (1993) study about environmental risk factors, Stanton-Chapman, Kaiser and Hancock (2004) studies about identification abouth risk factors. Although there are studies about identification of environmental factors in Turkey; however, studies which measure the environmental risk factors affecting the children's development are not common.

Studies show that the need to measure environmental factors is increasing. Perceived Environmental risk Factors (PERF) scale's sub-dimensions which are perceptions relatedto environmental risk factors percieved by elementary school students, put in order to perceptions of in-school experience, perceptions of oneself, perceptions of family attitudes, perceptions of family interactions, perceptions of problems within the family, perceptions the nearest living area. For example, 'perception of school life' helps to explain the child's personal fit regarding school, friends and teacher. 'Children's perception of themselves' covers self- acceptance and self-esteem which both higlight the perception of themselves. Also, the child perception of the family attitudes highlights the perception of family social support, appreciaton of family, expectations of future, love and respect. The perceptions of family interaction cover reltionships between child and family members. Perceptions of problems within the family cover spousal, parent-child and sibling relationship problems in a domestic sub-system. Perceptions the nearest living area covers the relationship between child and close vicinity where children live, grandparents, close relatives, neighbors. 
Özabacı, N., \& Yeșilkaya, E. (2016). Perception of Environmental Risk Factors Scale for the primary school students. Journal of Human Sciences, 13(2), 3150-3159. doi:10.14687/ihs.v13i2.3743

\subsection{Purpose of The Study}

The purpose of this study was to develop a scale that can measure children's perceptions which are affected by environmental risk factors and was to test the reliability and validity of this scale. This scale was developed to be used in epidemiological research and clinical intervention studies on children in Turkey. In this study Perceptions of the Environmental Risk Factors Scale's (PERF) psychometric properties are presented and discussed.

\section{Method}

\subsection{Sample}

In this research, participants who are conducted in a study for the development of "Perception of the Environmental Risk Factors Scale" are composed of primary school students studying at fifth, sixth, seventh and eighth graders' in Gaziantep. In this study, neither was the universe defined nor a sample based on the universe.

Working group was established to ensure such features as affordability, accessibility to the crowd of students, the implementation and collection of scales and traceability. In this study, participant's selection was made according to the District National Ministry of Education's list of regions according to the socio economic level. The selection was made from this list with the method of drawing lots. Selected from two schools; 147 fifth grade, 112 sixth grade, 93 seventh grade, 57 eight grade students participated in the study; in total the study includes 409 participants. The mean age of participants is 12,12. Fifth, sixth, seventh and eighth grade level students are selected to achieve the objective of the study.

\subsection{Procedures}

In order to develop scale items, some related studies abroad and the country have been done. Based on the examined studies, an 81-point scale item pool was created by taking into account a number of factors that were born from the immediate vicinity of the students and their environments and that are thought to affect these students negatively. Then, a pre-form was transformed into a likert type scale. This scale was presented to the opinion of two experts from Measurement and Evaluation and Counseling and Guidance Departments. As a result of these experts' arrangement of the items of the scale, needed corrections were made.

Survey data were collected by the researcher. The participants were given prior information about scale. Participants were asked to fill out the scale and socio-demographic information about the scale. Participants were asked to fill out the scale and socio-demographic information form. To complete these forms took the participants approximately 45 minutes.

\subsection{Data Collection}

Data collection of the research is Perception of the Environmental Risk Factor Scale and demographic form which include some questions about gender, class level etc. In the preparation of the personal information sheet, the sub-headings were prepared and tookintoaccount study of Bacanli (1997).

\subsection{Data Analysis}

A descriptive analysis of the study, and group comparisons were made with SPSS 16.0. Confirmatory factor analysis was performed using LISREL. RMSA value was sought to be under .08 and CFI value acceptable over .95 . 
Özabacı, N., \& Yeșilkaya, E. (2016). Perception of Environmental Risk Factors Scale for the primary school students. Journal of Human Sciences, 13(2), 3150-3159. doi:10.14687/jhs.v13i2.3743

\section{Results}

In order to determine the structure of the scale, a confirmatory analysis (CRA) was conducted. The Kasier Meyer Olkin (KMO) analysis was conducted in order to determine the appropriateness of the factor analysis. Besides, the Bartlett Test was made use of to determine whether a relationship between the items existed or not. The measure of the self-worth was used in determining the factors which include items involved in rotated principal components factor analysis was used. As a result of the analysis the KMO value of the scale was .84 which is good value in terms of factoring. It is accepted that value .90 is excellent, .80 is very good and .70 is good to evaluate the KMO data (Büyüköztürk, 2010). To determine how many factors the scale is composed of distribution of eigen values was analyzed according to the scree plot scale chart that shows the total variance of each factor. The region up to the point of the graph shows the maximum number of factors to be obtained (Kalayc1, 2006). As a consequence of the analysis six factors were determined according to the chart. The first factor explains $10.3 \%$ of total variance, second $9.5 \%$, third $8.3 \%$, fourth $8.1 \%$, fifth 7.4 and the sixth factor explain $4.3 \%$ of the total variance. The result of the KMO and Bartlett test are in Table 1.

Table 1. KMO and Bartlett's Test Results

\begin{tabular}{lcc}
\hline KMO coefficient & & .849 \\
Bartlett Test & $\chi^{2}$ & 10335.709 \\
& $\mathrm{~s}$ & 1485 \\
& $\mathrm{p}$ & .000 \\
\hline
\end{tabular}

Table 2. Compliance Values of PERF Scale Regarding Conformity Assessment

\begin{tabular}{ccc}
\hline Compliance Measurements & Good Fit & Research Model \\
\hline RMSEA & & \\
GFI & $0-0.05$ & 0.04 \\
AGFI & $0.90-1$ & 0.85 \\
NNFI & $0.90-1$ & 0.83 \\
\hline
\end{tabular}

Table 2 shows the results of confirmatory analysis. Based on these results RMSA=.04,GFI=.85, $\mathrm{AGFI}=.83$, NNFI $=.95$.

As a result of the factor rotation operations, the first factor of the scale contains thirteen items, second twelve items, third ten items, fourth nine items, fifth seven items and the sixth factor contains four items. The load value of substances within the scope of the first factor has value between .44 and .78; second factor between .53 and .74, third factor between .48 and .73; fourth factor between .49 and .79, fifth factor between .55 and .78, and the sixth factor has value between .55 and .42. Each dimension of the scale is named taking into consideration the subject it involves. The first dimension is named 'Perceptions of In-School Experience', second 'Perceptions of Oneself', third 'Perceptions of Family Attitudes', fourth 'Perceptions of Family Interactions', fifth 'Perceptions of Problems Within the Family' and the sixth dimension is named 'Perceptions of the the Nearest Living Area'. Cronbach Alpha for the scale was found to be .85. Questions are grouped according to the value in the scale load factors. Some items which have the highest value in more than one factors are removed (The items $77,43,49,46$ ). As a result of the analysis, it has been determined that the scale has a structure composed of six factors and 55 items. The confirmatory factor analysis results in Table 3. 
Özabacı, N., \& Yeşilkaya, E. (2016). Perception of Environmental Risk Factors Scale for the primary school students. Journal of Human Sciences, 13(2), 3150-3159. doi:10.14687/jhs.v13i2.3743

Table 3.Principal Component Analysis

\begin{tabular}{|c|c|c|c|c|c|c|c|}
\hline Items & $\begin{array}{l}\text { Value Label } \\
\text { Subdimensi } \\
\text { on } 1\end{array}$ & $\begin{array}{l}\text { Value } \\
\text { Label } \\
\text { Subdimens } \\
\text { ion } 2\end{array}$ & $\begin{array}{l}\text { Value Label } \\
\text { Subdimensi } \\
\text { on } 3\end{array}$ & Items & $\begin{array}{l}\text { Value Label } \\
\text { Subdimensio } \\
\text { n } 4\end{array}$ & $\begin{array}{l}\text { Value Label } \\
\text { Subdimensio } \\
\text { n } 5\end{array}$ & $\begin{array}{l}\text { Value Label } \\
\text { Subdimensi } \\
\text { on } 6\end{array}$ \\
\hline M62 & .786 & & & M18 & .748 & & \\
\hline M66 & .773 & & & M19 & .722 & & \\
\hline M65 & .706 & & & M24 & 687 & & \\
\hline M68 & .665 & & & M17 & 683 & & \\
\hline M63 & .647 & & & M22 & .661 & & \\
\hline M67 & .645 & & & M25 & .616 & & \\
\hline M61 & .623 & & & M23 & .596 & & \\
\hline M52 & .613 & & & M20 & .572 & & \\
\hline M64 & .587 & & & M21 & .491 & & \\
\hline M56 & .572 & & & M30 & & .781 & \\
\hline M57 & .558 & & & M11 & & .771 & \\
\hline M51 & .525 & & & M29 & & .758 & \\
\hline M53 & .441 & & & M12 & & .758 & \\
\hline M74 & & .740 & & M31 & & .746 & \\
\hline M72 & & .694 & & M13 & & .732 & \\
\hline M70 & & .659 & & M37 & & .550 & \\
\hline M73 & & .652 & & M50 & & & .634 \\
\hline M71 & & .650 & & M48 & & & .584 \\
\hline M69 & & .636 & & M47 & & & .530 \\
\hline M80 & & .618 & & M45 & & & .425 \\
\hline M79 & & .605 & & & & & \\
\hline M78 & & .561 & & & & & \\
\hline M75 & & .561 & & & & & \\
\hline M81 & & .541 & & & & & \\
\hline M76 & & .532 & & & & & \\
\hline M8 & & & .734 & & & & \\
\hline M9 & & & 692 & & & & \\
\hline M2 & & & 688 & & & & \\
\hline M10 & & & 669 & & & & \\
\hline M1 & & & .639 & & & & \\
\hline M5 & & & .616 & & & & \\
\hline M3 & & & .579 & & & & \\
\hline M7 & & & .556 & & & & \\
\hline M14 & & & .534 & & & & \\
\hline M4 & & & .488 & & & & \\
\hline $\begin{array}{l}\text { Eigen } \\
\text { Value }\end{array}$ & 8.6 & 6.4 & 4.2 & & 2.8 & 2.2 & 2.0 \\
\hline
\end{tabular}

Consequently, the fact that the scale consists of 55 items and 6 subtitles is determined by the alignment makers of the confirmatory factor analysis, and this model is found to comply with the theoretical and statistical points of the scale. When factor loadings are analyzed it is observed that range of factor loadings changed between .42 and .79. These values show the factor loadings of the substances are at an adequate level. When the model fit is examined the covariance between observed variables and difference between parameter covariance matrix is used. Difference 
between parameter covariance matrix proposes in the model, in other words fit index which developed on the bases of the error degree. The RMSEA is the root mean square error of approximation, and it is expected that RMSEA range is about 0.05 or less than 0.05 for a meaningful model. Taking a range between 0.05 and 0.08 indicates a better model fit. SRMR is standardized root mean square residual, SRMR values approaching the 0 indicates a better model fit. Model values below 0.05 indicate a good model fit. A SRMR value range between 0.05 and 0.10 indicates an acceptable model fit. GFI is the goodness-of-fit statistic. GFI indicates the amount of general covariance between observed variables. It can be explained as $\mathrm{R}^{2}$ in regression analysis. Having lots volume sample can prevent an accurate result because of raising GFI value. The GFI value changes between 0 and 1. A GFI value 0.90 or greater than 0.90 indicates a good model fit. When GFI values fall in this range calculate covarience is accaptable for research (Ayylldı \& Cengiz, 2006). AGFI is adjusted goodness of fit index. It is a kind of GFI value which is corrected considering the number of samples. Particularly in some cases, where the sample size is larger, AGFI is of a more representative fit index. AGFI value is between 0 and 1. Approaching value to 1 shows better model fit. CFI is the comparative fix index. It compares the current model and 0 hypothesis model which ignores the covariance between latent variables. So, it compares covarience matrix of the zero hypotesis and estimated covarience matrix by the new model (Ayyldız \& Cengiz, 2006). CFI takes values between 0 and 1. A value between 0.97 and 1 indicates good model fit, a value between 0.90 and 0.97 indicates an acceptable model fit. NFI is the normed fit index, and it has been developed as an alternative to CFI. It is positevely related with the number of samples. This index explores the correspondence between the null and basaline model. It takes values between 0 and $1 \mathrm{~A}$ value of between 0.95 and 1 indicates good model fit, between 0.90 and 0.95 indicates an acceptable model fit. NNFI, non-normed fit index, is not affected by the increase in the number of samples. Although moving from the assumption of normality, generally its value is between 0 and 1, sometimes it may be out of range (Şehribanoğlu, 2005). A value of between 0.95 and 0.97 indicates good model fit, between 0.95 and 0.97 indicates accaptable model fit. It is suggested that the fit index should be greater than 0.90 value and error fit index should be smaller than 0.05 value. In other words GFI, AGFI, CFI values should be over rated 0.90 as well as SRMR and RMSE values should be less than 0.05 (Schumacker \& Lomax, 1996). PERF scale is determained as consisting of 55 items and six sub-dimensions by the relative fit indicates. (Figure 1).
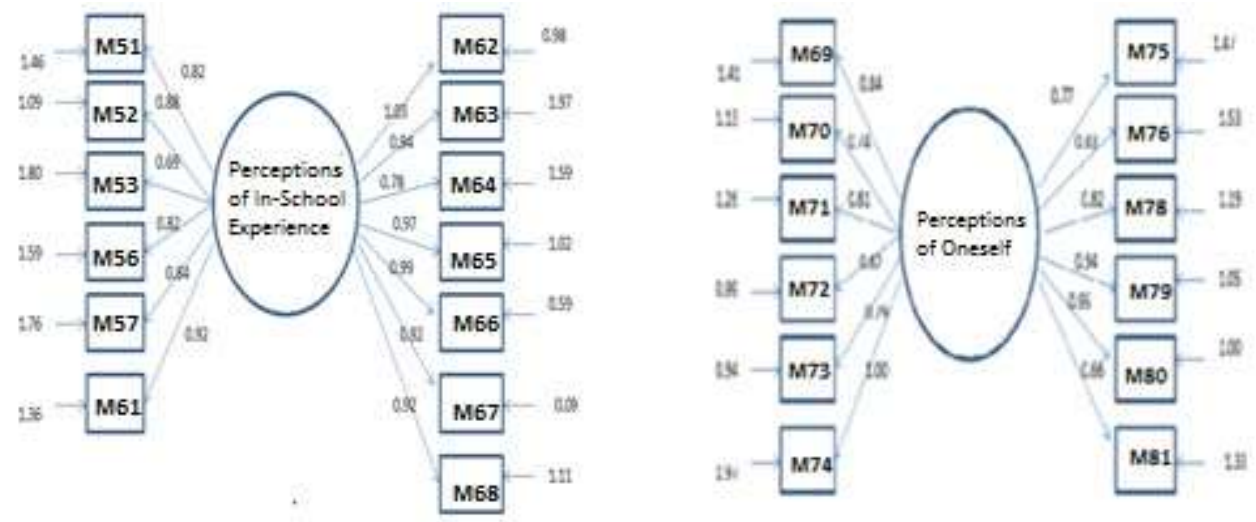

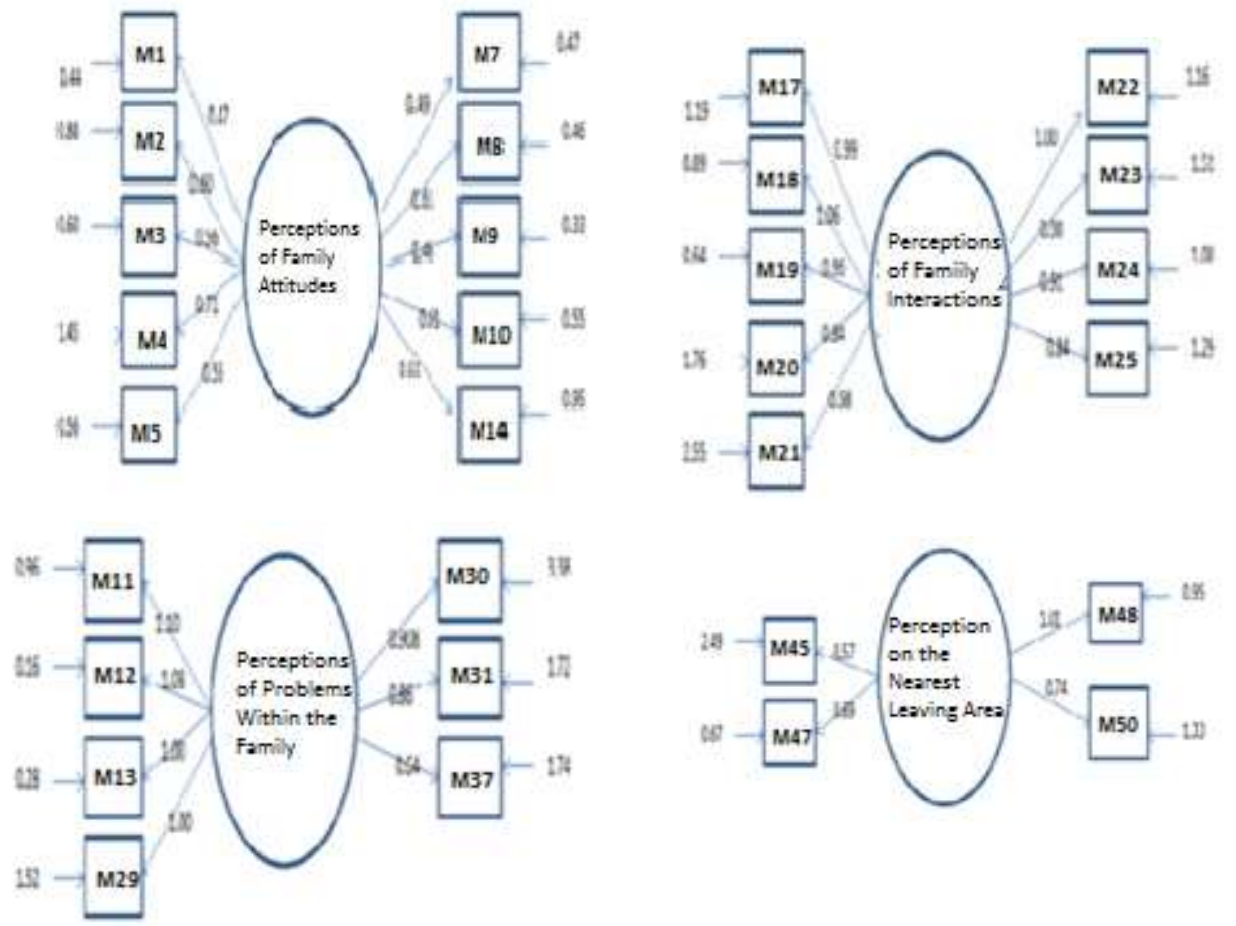

Figure 1.Confirmatory Factor Analysis Results for the PERF scale

In this study, the reliability of the scale was examined via the coefficient internal consistency. The internal consistency of the scale was found to be .85. The results related to the internal consistency calculations are presented in Table 4.

Table 4. Reliability Analysis Results PERF Scale

\begin{tabular}{cc}
\hline Cronbach Alpha & The number of items \\
\hline .85 & 55 \\
\hline
\end{tabular}

\section{Discussion}

In this study, the variables, which are in the vicinity of the primary school students and thought to be a risk factor, were analyzed. The study limited with the analysis of the items that consist of subdimensions: 'Perceptions of In-School Experience', 'Perceptions of Oneself, 'Perceptions of Family Attitudes', 'Perceptions of Family Interactions', 'Perceptions of Problems Within the Family' and 'Perceptions of the Nearest Living Area'. The validity and reliability of the findings of the scale show that the scale is suitable for students who are attending at $5^{\text {th }}, 6^{\text {th }}, 7^{\text {th }}$ and $8^{\text {th }}$ grade level. Since the study is done only for these grade level students, further valid and reliabile studies can be offered for the scale to be used on other groups of the specified grade level.

While developing the scale's items, the risk factors taking point in the study of Sameroff etal. (1993) and Hooper et al. (1998) were taken into consideration. Sub-dimension of the scale were achieved as a result of the analysis of the items namely, family, school environment, parent-child interactions and daily living environment. This study limited with some variables as family problems, permanent illness status, number of people living in the family, the parents status and and health status of the individual. Sentences are written as taken into account factors which take place of individuals and affect them negatively. The first factor includes 13 items to determine the students perception of 
Özabacı, N., \& Yeșilkaya, E. (2016). Perception of Environmental Risk Factors Scale for the primary school students. Journal of Human Sciences, 13(2), 3150-3159. doi:10.14687/ihs.v13i2.3743

school and the school environment. The second factor includes twelve items to determine the students' perception and thinking about themselves. The third factor includes ten items to determine the students' perception of family attitudes. The fourth factor includes nine items to determine students' perception about the interaction between family members, family status and its effect on participation in social activities and nutrition. The fifth factor includes the seven items to determine students' perception of the familial problems, the family's attitude towards the student and the health status of students and family members. The sixth factor includes four items to determine situations which determined students' surroundings that could adversely affect them.

In 17 item questionnaire developed by Bulut (2010), items which cover domestic violence, immigration, education and socio-economic status prepared to measure the familial factors impact on adolescents. In her/his study on the factors leading to the hopelessness of fifth grade students Gerede (2002) state that, the children's hopelessness level differs according to their mothers' attitude, family income, social support and social skill level within the family, parents educational level and occupational status of parents. However, Gerede states that the children's hopelessness level does not depend on parental attitude and intensities of traumatic experiences. Besides these determinants of the psychometric properties of PERF scale, it can be said that this scale is suitable for research and clinical applications. First, PERF scale seems to be a convenient tool for future studies which could be based on environmental risk factors. Second, it can be used to determine the child's relationship with the environment and problems arising from these relationships; it can be used when studying in risk areas and large group relations which cover family members, friends and their close vicinity. Besides, the scale can be used as a guiding for the primary education guidance and counseling studies.

A limitation of this study is that the sample is limited to a particular age range. In further studies, including a wider age group of young individuals in the scale factor structure of the testing would be useful. In addition, participants were not examined for the presence of psychiatric illness. The results of this study can be used by particularly by counselors, psychologists, psychiatrists, social workers, special educators, and researchers for their own purposes. In particular, social counselors can make use of this scale in order to collect information about the risk factors in the children surrounding preventive counseling. School counselors detecting children with problem behavior and the risk factors for these children can do preventive counseling.

\section{Conclusions}

As a result of the analysis, it has been determined that the scale has a structure composed of six factors and 55 items. The name of the factors; perceptions of in-school experience, perceptions of oneself, perceptions of family attitudes, perceptions of family interactions, perceptions of problems within the family, detects the nearest living area. Cronbach Alpha for the scale was found to be .85 .

The results suggest that the environmental risk factors are very important to evaluate the children developmental process. A scale is necessary for evaluate the factors for children. This scale with six sub scale and 55 items will be useful for educators to define the risk factors for children. The moderating effects of ethnicity and gender were also explored. Low income and minority ethnic status are significant risk factors for children's achievement and development. A large impact of life events the effects of such events achievement appear to be best understood as part of the larger context of multiple risk factors during childhood (Burchinal, Kupersmidt, Patterson \& Pungello, 1996).

In this study, ÇRFA was developed which consisted six sub scale. KMO and Bartlett test were made for exploratory factor analysis and Lisrel was used for confirmative factor analysis. 
Özabacı, N., \& Yeșilkaya, E. (2016). Perception of Environmental Risk Factors Scale for the primary school students. Journal of Human Sciences, 13(2), 3150-3159. doi:10.14687/jhs.v13i2.3743

Depending on the results of analysis can be said that this model acceptable statistically and theoretically.

\section{References}

Akgün, Ö., Büyüköztürk, Ş., Çakmak, E., Demirel, F. \& Karadeniz, Ş. (2009). Bilimsel araştırma yöntemleri. (4th ed.). Ankara: Pegem Akademi Press.

Appleyard, K., Egeland, B., Dulmen, M. H. M. \& Sroufe, L. A.(2005) When more is not better: the role of cumulative risk in child behavior outcomes. Journal of Psychology,46(3), 235-245.

Ayyıldız, H., Cengiz, E. \& Ustasüleyman, T. (2006). Üretim ve pazarlama bölüm çalışanları arası davranışsal değişkenlerin firma performansı üzerine etkisine ilişkin yapısal bir model önerisi. Mugla University Journal of Social Sciences, 17.

Bacanl,H. (1990). Kendini ayarlama becerisinin çeşitli değişkenlerle ilişkisi. (Doctoral dissertation). Retrieved from https://tez.yok.gov.tr/UlusalTezMerkezi/, University of Ankara, Ankara.

Bacanlı, H. (1997). Sosyal ilişkilerde benlik: Kendini ayarlamanın psikolojisi. MEB Press No. 905, İstanbul.

Balc1, A. (2009). Sosyal bilimlerde arastırma yöntem, teknik ve ilkeler. Ankara: Pegem Akademi Press.

Bearinger, L. H., Blum, R. W. Saewyc, E.M., Skay, C.L., \& Resnick, M.D. (1998).Demographics of sexual orientation among American-Indian adolescents. AmericanJournal of Orthopsychiatry, 68(4): 590-600.

Brooks-Gunn, J., Klebanov P., Liaw F. \& Spiker D. (1993). Enhancing the development of low birthweight, premature infants: Changes in cognition and behavior over the first three years, Child Development, 64, 736-753.

Bronfenbrenner, U. (1979). The ecology of human development experiments by natüre and desing. Cambridge, Massachusetts: Harvard University Press.

Bulut, F. (2010). Ergenlerde görülen kural dışı davranıslarn aile işlevselliüi aile risk faktörü ve yașam kalitesi açsindan incelenmesi. (Master dissertation). Retrieved from https://tez.yok.gov.tr/UlusalTezMerkezi/, Çukurova University, Adana.

Burchinal, M. R., Pungello, E, P.,Kupersmidt, J. B. \& Patterson, C. J. (1996). Environmental risk factors and children's achievement from middle childhood to early adolescence. Developmental Psychology, 32(4), 755-767.

Burchinal, M. R., Hooper, S. R., Roberts, J. E., Zeisel, S. A. \& Neebe, E. C. (1998). Social and family risk factors for infant development at one year: An application of the cumulative risk model. Journal of Applied Developmental Psychology, 19(1), 85-96.

Büyüköztürk, Ş. (2010). Veri analiri el kitabı. (11th ed.). Ankara: Pegem Akademi Press.

Byrne, B. M. (2001). Structural equation modelling with AMOS. New Jersey: Lawrence Erlbaum Associates.

Erkan, Z. (2002). Ergenlerin sosyal kayg düzeyleri, ana-baba tutumlar ve ailede görülen risk faktörleri üzerine bir çalssma. (Doctoral dissertation). Retrieved from https://tez.yok.gov.tr/UlusalTezMerkezi/, Çukurova University, Adana.

Garmezy, N. (1985). Stress resistant children: The search for protective factors, Recent Research in Developmental Psychology. Journal of Child Psychology and Psychiatry Book Supplement, 4, 213-233.

Gerede, A. (2002). Illköğretimde okuyan çocuklarn umutsuðluk düzeylerinin çesitili değiskeenler açsından Incelenmesi. (Master dissertation). Retrieved from https://tez.yok.gov.tr/UlusalTezMerkezi/ Anadolu University, Eskişehir. 
Özabac1, N., \& Yeşilkaya, E. (2016). Perception of Environmental Risk Factors Scale for the primary school students. Journal of Human Sciences, 13(2), 3150-3159. doi:10.14687/jhs.v13i2.3743

Jessor, R., Van Den Bos, J., Vanderryn, J., Costa, F. M. \& Turbin, M. S. (1995). Protective Factors in Adolescent Problem Behavior: Moderator Effect and Developmental Change. Developmental Psychology, 31(6), 923-933.

Kalayc1, S. (2006). SPSS uygulamal çok değģskenli istatistik teknikleri. (2nd ed.). Ankara: Asil Press.

Öztürk, H., Sevindik, F. N. \& Yaman, S. Ç. (2006). Ögrencilerde yalmąhk ve sosyal destek ile bunlar etki eden faktörlerin incelenmesi, F.U. Turkish Journal of Social Science 16(1), 383-394.

Sameroff, A. J., Seiffer, R., Baldwin, A. \& Baldwin, C. (1993). Stability of intelligence from preschool to adolescence; the influence of social and family risk factors. Child Development, 64: $80-97$.

Sarıtaş, M. (2006). İlkëğretim 7. ve 8. sinf ögrrencilerinde gözlenen davranıslarm aile sorunlarna göre incelenmesi. (Master dissertation). Retrieved fromhttps://tez.yok.gov.tr/UlusalTezMerkezi/, KATÜ, Trabzon.

Siyez, D. (2006). Ergenlik döneminde intihar girişimleri: Bir gözden geçirme. Kastamonu Education Journal, 14(2), 413-420.

Smith-Bird, E. \& Turnbull, A. (2005). Linking positive behavior support to family quality-of-life outcomes. Journal of Positive Behavior Interventions, 7(3), 174-180.

Stanton- Chapman, T.L., Chapman, D.A., Kaiser, A.P. \& Hancock, T.B. (2004).Cumulative risk and low-income children's language development. Early Childhood Special Education, 244, 227237.

Schumacker, R.E. \& Lomax, R.G. (1996). A beginner's guide to structural equation modeling. Mahwah, New Jersey: Lawrence Erlbaum Associates, Publishers.

Şehribanoğlu, S. (2005). Yapısal esittik modelleri ve bir uygulaması. (Master dissertation). Retrieved from https://tez.yok.gov.tr/UlusalTezMerkezi/, Van Yuzuncu Yul University Institute of Sciences Department of Zoo Technology.

Tavşancıl, E. (2006). Tutumlarn ölçülmesi ve SPSS ile veri analizi. Ankara: Nobel Press.

Ünal, A. (2006). İlkögretim ögrencilerinin gelecek ile ilgili umutlarmm yapusal eşitlik modelleriylebelirlenmesi.(Masterdissertation).Retrievedfromhttps://tez.yok.gov.tr/UlusalTezMe rkezi/, Eskişehir Osmangazi University, Eskişehir.http://www.tdk.gov.tr (Date of access: 09.06.2011,11.08.2011) 